\title{
Pengaruh Pola Agitasi pada Reaksi Transesterifikasi Minyak Jelantah Warung Pecel Lele Menggunakan Katalis Kitosan
}

\author{
Tatang Shabur Julianto ${ }^{a}$ dan Thorikul Huda ${ }^{b}$

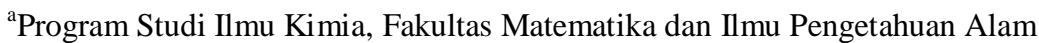 \\ Universitas Islam Indonesia, Yogyakarta \\ ${ }^{\mathrm{b}}$ Program D3 Analis Kimia, Fakultas Matematika dan Ilmu Pengetahuan Alam \\ Universitas Islam Indonesia, Yogyakarta \\ e-mail: tatang_shabur@staff.uii.ac.id
}

\begin{abstract}
Effect of agitation on the transesterification reaction of waste cooking oil from pecel lele food stalls around UII campus using chitosan catalyst. Transesterification reaction was done by adding 46 grams of chitosan and $123 \mathrm{~mL}$ metanol tothe reactor. The mixture was stirred for 30 minutes to distribute methanol into chitosan. Furthermore, $500 \mathrm{~mL}$ (460 grams) of cooking oil ( $\rho=0.916 \mathrm{~g} / \mathrm{mL}$ ) was add into reactor and agitated at $65^{\circ} \mathrm{C}$ within two hours using $30 \mathrm{rpm}$ speed. Agitation was performed with several variations of the direction of stirring, one way stirring, stirring 2 ways round the turn at intervals of 5, 10 and 15 minutes. The results show that only 49,95\% methyl ester yieldwas obtained (methyl palmitate, methyl-9octadecenoate, methyl-3-oxooctadecanoate), produced by one directional rotation. Two ways agitation gives methyl ester results on average by $30.41 \%$. The number of methyl ester was decreased when treated with two way stirring well in intervals of 5 seconds (30.34 \%), 10 seconds (29.97\%) and 15 seconds (30.94\%). Methyl ester product was only sligtly, presumably because the raw material is very bad used cooking oil. It can be indicated from thehigh acid number $8.11 \mathrm{mg} / \mathrm{L}$. and the number of chemical components in addition to triglycerides which may interfere with or hinder the contact between the reactants (chitosan, methanol and triglycerides).
\end{abstract}

Keywords: used cooking oil, chitosan, agitation, transesterification, methyl ester

\begin{abstract}
ABSTRAK
Telah dilakukan penelitian tentang pengaruh pola agitasi pada reaksi transesterifikasi minyak jelantah warung pecel lele di sekitar kampus Universitas Islam Indonesia menggunakan katalis kitosan. Reaksi transesterifikasi dilakukan dengan terlebih dahulu memasukkan 46 gram katalis heterogen kitosan reaktor bersama $123 \mathrm{~mL}$ metanol. Campuran diaduk selama 30 menit dengan tujuan untuk mendistribusikan metanol ke dalam kitosan. Selanjutnya sebanyak $500 \mathrm{~mL}(460$ gram $)$ minyak jelantah $(\rho=0,916 \mathrm{~g} / \mathrm{mL})$ dimasukkan ke dalam reaktor dan diaduk dengan temperatur $65^{\circ} \mathrm{C}$ dalam waktu dua jam. Kecepatan yang digunakan sebesar $30 \mathrm{rpm}$. Agitasi dilakukan dengan beberapa variasi yaitu pengadukan searah, pengadukan 2 arah dengan interval pergantian putaran 5 menit, 10 menit dan 15 menit.Hasil menunjukkan bahwa metil ester yang terbentuk paling tinggi hanya diperoleh 49,95\% (methyl palmitate, methyl-9-octadecenoate, methyl-3-oxooctadecanoate) yaitu pada agitasi dengan putaran searah. Agitasi 2 arah memberikan hasil metil ester rata-rata sebesar 30,41\%. Dari data tersebut nampak terjadi penurunan jumlah ester pada saat diperlakukan dengan pengadukan 2 arah baik dalam interval 5 menit (30,34\%), 10 menit (29,97\%) maupun 15 menit (30,94\%). Metil ester yang dihasilkan hanya sedikit, diduga karena bahan baku yang digunakan adalah minyak jelantah yang sangat buruk. Hal ini dapat diindikasikan dari angka asam yang cukup tinggi yaitu $8,11 \mathrm{mg} / \mathrm{mL}$, serta banyaknya komponen kimia selain trigliserida yang dapat mengganggu atau menghalangi terjadinya kontak antar reaktan (kitosan, metanol dan trigliserida).
\end{abstract}

Kata kunci:minyak jelantah, kitosan, agitasi, transesterifikasi, metil ester. 


\section{Pendahuluan}

Metode pembuatan biodiesel yang umum digunakan saat ini adalah melalui proses transesterifikasi minyak nabati menggunakan katalis basa. Dalam reaksi ini alkohol seperti metanol dan etanol, ditambahkan ke dalam trigliserida menggunakan katalis basa homogen seperti $\mathrm{NaOH}, \quad \mathrm{KOH}$, dan $\mathrm{NaOCH}_{3}$. Proses ini berjalan cepat dan efisien pada temperatur yang relatif rendah (Srivastava, 2000). Meskipun demikian biaya produksi biodiesel masih mahal dan menjadi issu penting. Biaya produksi tersebut dapat dikurangi dengan cara pemilihan bahan baku yang murah dan efisiensi proses (Zappi, 2003). Sebagai contoh, saat ini bahan baku murah yang banyak digunakan adalah minyak non pangan seperti jarak pagar (Jatropha curcas) (Parawira, 2010) dan minyak jelantah (Patzer, 2002).Dalam penelitian sebelumnya, Tatang (2011) telah menggunakan kitosan sebagai katalis basa heterogen dalam reaksi transesterifikasi minyak jelantah dengan hasil metil ester sebesar $86 \%$. Reaksi tersebut dilakukan pada temperatur $65^{\circ} \mathrm{C}$ selama dua jam dengan agitasi putaran searah. Agitasi merupakan salah satu faktor penting yang dapat mempercepat laju reaksi kimia oleh aksinya memberikan energi kinetik partikel lebih besar dan meningkatnya jumlah tumbukan antar reaktan sehingga jumlah produk juga meningkat

\section{Tujuan Penelitian}

Tujuan penelitian ini adalah untuk mengetahui pengaruh pola agitasi pada reaksi transesterifikasi dengan katalis kitosan dan menggunakan bahan baku minyak jelantah yang berasal dari warung pecel lele di sekitar kampus UII.

\section{Metode Penelitian}

Alat-alat yang digunakan dalam penelitian ini adalah seperangkat alat gelas,seperangkat reaktor dengan putaran yang dapat diatur arah putaran dan temperaturnya, Gas Chromatography-Mass Spectrometer (Shimadzu QP-2010S). Bahan-bahan yang digunakan dalam penelitian ini adalah kitosan (LIPI Yogyakarta), minyak jelantah warung pecel lele di sekitar kampus UII, metanol teknis, aquades, $\mathrm{Na}_{2} \mathrm{SO}_{4}$ anhidrat Merck.

\section{Cara Kerja}

\section{Preparasi Minyak Jelantah}

Minyak jelantah yang diperoleh disaring menggunakan kertas saring untuk memisahkan partikel-partikel besar yang menjadi pengotor dalam minyak. Selanjutnya minyak dipanaskan pada temperatur $120^{\circ} \mathrm{C}$ untuk menghilangkan kandungan air

\section{Penentuan Angka Asam Minyak Jelantah}

Sampel minyak jelantah sebanyak 5 gram dimasukkan kedalam labu ukur $10 \mathrm{~mL}$, kemudian ditambahkan etanol sampai tanda 
batas.Campuran tersebut kemudian dipindahkan ke dalam erlenmeyer dan dipanaskan pada temperatur $60^{\circ} \mathrm{C}$ selama 10 menit diatas penangas air sambil diaduk. Setelah larutan dingin selanjutnya dititrasi dengan $\mathrm{KOH}$ 0,13 M yang telah distandarisasi menggunakan larutan asam oksalat dan ditambah indikator phenolptalein hingga berwarna merah muda dan titrasi dilakukan sebanyak 2 kali. Volume $\mathrm{KOH}$ yang digunakan untuk menitrasi hingga berwarna merah muda kemudian dicatat dan kemudian dihitung kandungan angka asamnya.

\section{Pembuatan Metil Ester (Reaksi} Transesterifikasi)

$\begin{array}{cccc} & \text { Reaksi transesterifikasi dilakukan } \\ \text { dalam reaktor putaran bolak-balik yang }\end{array}$ dilengkapi pengaduk otamatis bolak-balik dan heater. Sebanyak 46 gram kitosan dimasukkan ke dalam reaktor bersama dengan $123 \mathrm{~mL}$ metanol dan $500 \mathrm{~mL}$ minyak jelantah. Komposisi minyak dan metanol didasarkan pada rasio mol 1:12 dengan asumsi trigliserida minyak jelantah didominasi oleh jenis Palmitat-Oleat-Oleat (OOP) dengan berat molekul sebesar $856 \mathrm{~g} / \mathrm{mol}$ dan berat molekul metanol sebesar 32,04 gram/mol. Selanjutnya pengaduk dan pemanas dinyalakan dengan temperatur konstan pada $60^{\circ} \mathrm{C}$ selama 2 jam. kecepatan pemutaran diatur $30 \mathrm{rpm}$ dengan variasi putaran searah, putaran 2 arah dengan interval waktu pergantian putaran tiap 5 menit, 10 menit, dan 15 menit. Selanjutnya hasil metil ester dipisahkan dari gliserol dan kitosan, kemudian dianalisis menggunakan Gas Chromatography-Mass Spectrometer.

\section{Pembahasan}

\section{Karakterisasi katalis kitosan}

Sebelum digunakan sebagai katalis, kitosan dihitung derajat deasetilasinya terlebih dahulu.Perhitungan besarnya derajat deasetilasi kitosan ditentukan menggunakan metode baseline yang diusulkan oleh Domszy dan Robert (1985) dengan menarik garis vertikal pada spektra yang dihasilkan dari analisis dengan FTIR yaitu serapan pada gugus hidroksi dan amida. Serapan pada $1655 \mathrm{~cm}^{-1}$ merupakan pita serapan karbonil pada amida sedangkan serapan pada $3450 \mathrm{~cm}^{-1}$ merupakan pita serapan gugus hidroksi. Spektra FTIR kitosan ditunjukkan pada gambar 1di bawah ini.

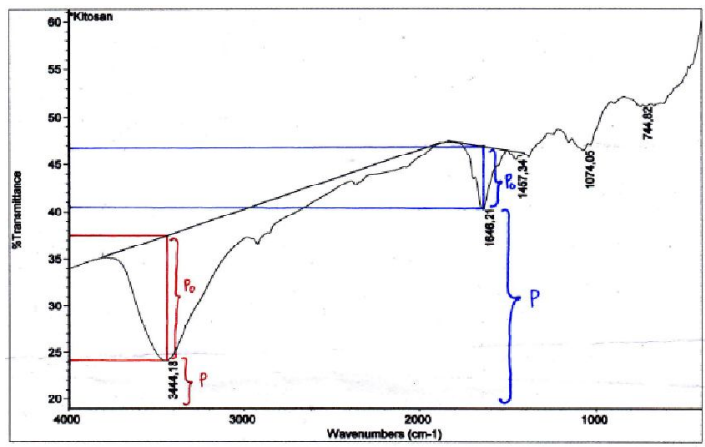

Gambar 1. Spektra FTIR kitosan

Po adalah \% transmitan pada garis dasar, $\mathrm{P}$ adalah \% transmitan pada puncak minimum dan A adalah absorbansi. Faktor 1,33 
merupakan nilai perbandingan $\mathrm{A}_{1646} / \mathrm{A}_{3444}$ untuk kitin yang telah terdeasetilasi sempurna.

$$
\begin{aligned}
\% \mathrm{DD} & =\left(1-\left(\frac{A_{1646}}{A_{3444}} \times \frac{1}{1,33}\right) \times 100 \%\right) \\
& =\left(1-\left(\frac{\log \frac{P o}{P}}{\log \frac{P 0}{P}} \times \frac{1}{1,33}\right) \times 100 \%\right) \\
& =\left(1-\left(\frac{\log \frac{47-40,5}{40,5-19}}{\log \frac{37,5-24,1}{24,1-19}} \times \frac{1}{1,33}\right) \times 100 \%\right) \\
& =\left(1-\left(\frac{0,611}{2,12}\right) \times 100 \%\right. \\
& =71,2 \%
\end{aligned}
$$

Dari hasil perhitungan diketahui bahwa kitosan yang digunakan sebagai katalis dalam penelitian ini memiliki dengan derajat deasetilasi sebesar $71,2 \%$

\section{Reaksi Transesterifikasi Minyak Jelantah}

Dalam penelitian ini digunakan minyak jelantah yang berasal dari warung pecel lele di sepanjang Jalan Kaliurang sekitar Kampus UII Terpadu. Preparasi minyak jelantah dilakukan dengan memisahkan endapan hingga diperoleh minyak jelantah yang jernih. Minyak jelantah yang digunakan ini berwarna coklat. Bilangan asam minyak jelantah sebesar $8,11 \mathrm{mg} / \mathrm{mL}$. Hal ini menunjukkan bahwa minyak jelantah memiliki asam lemak bebas yang cukup tinggi.

Reaksi transesterifikasi dilakukan dengan terlebih dahulu memasukkan 46 gram katalis heterogen kitosan reaktor bersama metanol. Campuran diaduk selama 30 menit dengan tujuan untuk mendistribusikan metanol ke dalam kitosan. Selanjutnya sebanyak 500 $\mathrm{mL}$ (460 gram) minyak jelantah $(\rho=0,916$ $\mathrm{g} / \mathrm{mL}$ ) dimasukkan ke dalam reaktor dan diaduk dengan temperatur $65^{\circ} \mathrm{C}$ dalam waktu dua jam. Komposisi kitosan dan minyak jelantah didasarkan pada penelitian sebelumnya bahwa berat optimal kitosan yang digunakan dalam reaksi transesterifikasi adalah sebanyak 1 gram untuk tiap 10 gram minyak jelantah. Kecepatan yang digunakan sebesar $30 \mathrm{rpm}$. Pengadukan dilakukan dengan beberapa variasi yaitu pengadukan searah, pengadukan 2 arah dengan interval pergantian putaran 5 menit, 10 menit dan 15 menit. Dari perlakuan tersebut diperoleh campuran dengan 3 lapisan, lapisan atas (metil ester dalam metanol), lapisan tengah (gliserol) dan lapisan bawah (kitosan) seperti yang ditampilkan dalam Gambar 2.

$$
\text { dalamnya. Komposisi tersebut }
$$

ditampilkan dalam tabel 1 .

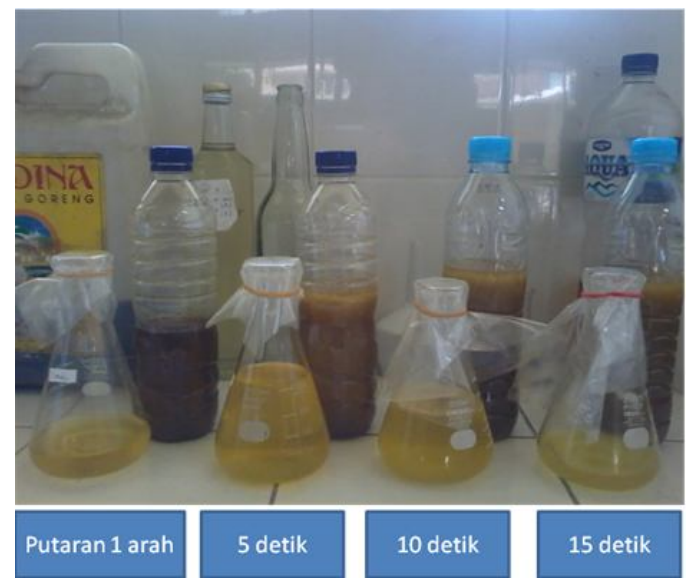

Gambar 2. Hasil reaksi transesterifikasi dengan variasi agitasi 
Larutan metil ester yang diperoleh selanjutnya dianalisis dengan Gas Chromatography-Mass

Spectrometer untuk mengetahui komposisi kimia yang ada di

Tabel 1. Komposisi produk transeterifikasi minyak jelantah dengan variasi agitasi

\begin{tabular}{|c|c|c|c|c|c|c|}
\hline & \multirow[b]{2}{*}{$\mathbf{R t}$} & \multirow[b]{2}{*}{ Nama Senyawa } & \multicolumn{4}{|c|}{$\%$ Area } \\
\hline & & & Putaran searah & $\underset{B}{\text { Putaran } 2} \underset{\text { arah intv. } 5 \text { menit }}{ }$ & Putaran 2 arah intv. 10 menit & $\begin{array}{c}\text { Putaran } 2 \text { arah intv. } 15 \text { menit } \\
\text { D }\end{array}$ \\
\hline $\begin{array}{l}\mathrm{A} \\
\mathrm{B} \\
\mathrm{C} \\
\mathrm{D} \\
\end{array}$ & $\begin{array}{c}- \\
19,79 \\
- \\
-\end{array}$ & 1-(1-heptadecynyl) cyclopentanol & - & 10,65 & - & - \\
\hline $\begin{array}{l}\mathrm{A} \\
\mathrm{B} \\
\mathrm{C} \\
\mathrm{D}\end{array}$ & $\begin{array}{c}- \\
- \\
- \\
20,37\end{array}$ & Alpha-ethylbenzenemethanol & - & - & - & 3,14 \\
\hline $\begin{array}{l}\text { A } \\
\text { B } \\
\text { C } \\
\text { D } \\
\end{array}$ & $\begin{array}{l}22,36 \\
22,35 \\
22,36 \\
22,36 \\
\end{array}$ & Methyl palmitate & 12,55 & 9,62 & 8,79 & 8,40 \\
\hline $\begin{array}{l}\mathrm{A} \\
\mathrm{B} \\
\mathrm{C} \\
\mathrm{D} \\
\end{array}$ & $\begin{array}{c}- \\
- \\
22,80 \\
-\end{array}$ & $\begin{array}{l}\text { Palmitic acid } \\
\end{array}$ & - & - & 5,69 & - \\
\hline $\begin{array}{l}\mathrm{A} \\
\mathrm{B} \\
\mathrm{C} \\
\mathrm{D} \\
\end{array}$ & $\begin{array}{l}24,19 \\
24,18 \\
24,19 \\
24,19 \\
\end{array}$ & Methyl-9-octadecenoate & 20,90 & 20,72 & 15,00 & 15,35 \\
\hline $\begin{array}{l}\mathrm{A} \\
\mathrm{B} \\
\mathrm{C} \\
\mathrm{D}\end{array}$ & $\begin{array}{c}24,68 \\
24,67 \\
24,67 \\
-\end{array}$ & 9-octadecenoic acid & 12,07 & 9,70 & 25,40 & - \\
\hline $\begin{array}{l}\text { A } \\
\text { B } \\
\text { C } \\
\text { D }\end{array}$ & $\begin{array}{c}- \\
24,84 \\
24,85 \\
-\end{array}$ & Ethyl heptadecanoate & - & 4,13 & 4,95 & - \\
\hline $\begin{array}{l}\mathrm{A} \\
\mathrm{B} \\
\mathrm{C} \\
\mathrm{D} \\
\end{array}$ & $\begin{array}{c} \\
- \\
- \\
25,04 \\
\end{array}$ & dodecylamide & - & - & - & 3,54 \\
\hline $\begin{array}{l}\mathrm{A} \\
\mathrm{B} \\
\mathrm{C} \\
\mathrm{D}\end{array}$ & $\begin{array}{c}- \\
26,02 \\
- \\
-\end{array}$ & 1-tridecene & - & 3,64 & - & - \\
\hline $\begin{array}{l}\text { A } \\
\text { B } \\
\text { C } \\
\text { D }\end{array}$ & $\begin{array}{c} \\
- \\
- \\
26,68\end{array}$ & $\begin{array}{l}\text { 9-octa } \\
\text { decenamide }\end{array}$ & - & - & - & 3,28 \\
\hline $\begin{array}{l}\mathrm{A} \\
\mathrm{B} \\
\mathrm{C} \\
\mathrm{D} \\
\end{array}$ & $\begin{array}{l}27,61 \\
27,60 \\
27,61 \\
27,61 \\
\end{array}$ & 1-chloro-7-heptadecene & 5,75 & 7,56 & 4,36 & 5,41 \\
\hline $\begin{array}{l}\mathrm{A} \\
\mathrm{B} \\
\mathrm{C} \\
\mathrm{D}\end{array}$ & $\begin{array}{c}- \\
27,73 \\
- \\
-\end{array}$ & Buthyl caproate & - & 5,25 & - & - \\
\hline $\begin{array}{l}\mathrm{A} \\
\mathrm{B} \\
\mathrm{C} \\
\mathrm{D}\end{array}$ & $\begin{array}{c}27,74 \\
- \\
27,74 \\
27,74 \\
\end{array}$ & $\begin{array}{l}\text { Methyl-3-oxoocta } \\
\text { decanoate }\end{array}$ & 6,50 & - & 6,18 & 7,19 \\
\hline $\begin{array}{l}\mathrm{A} \\
\mathrm{B} \\
\mathrm{C} \\
\mathrm{D}\end{array}$ & $\begin{array}{c}- \\
- \\
29,15 \\
29,14 \\
\end{array}$ & $\begin{array}{l}\text { 9-octadecenoic acid (z)-, 2,3- } \\
\text { bis[(trimethylsilyl)oxy]propyl ester }\end{array}$ & - & - & 3,01 & 5,23 \\
\hline $\begin{array}{l}\mathrm{A} \\
\mathrm{B} \\
\mathrm{C} \\
\mathrm{D}\end{array}$ & $\begin{array}{c}- \\
- \\
29,29 \\
29,28\end{array}$ & $(9 \mathrm{e}, 12 \mathrm{e})-9,12$-octadecadienoyl chloride & - & - & 3,99 & 9,47 \\
\hline $\begin{array}{l}\text { A } \\
\text { B } \\
\text { C } \\
\text { D }\end{array}$ & $\begin{array}{c}29,58 \\
- \\
29,57 \\
29,57\end{array}$ & $\begin{array}{l}\text { 9,12-octa } \\
\text { decadienoyl chloride }\end{array}$ & 21,31 & - & 3,38 & 20,02 \\
\hline $\begin{array}{l}\mathrm{A} \\
\mathrm{B} \\
\mathrm{C} \\
\mathrm{D}\end{array}$ & $\begin{array}{l}30,38 \\
30,37 \\
30,38 \\
30,37 \\
\end{array}$ & $\begin{array}{l}\text { 9-octa } \\
\text { decenamide }\end{array}$ & 8,91 & 6,17 & 6,13 & 9,53 \\
\hline $\begin{array}{l}\text { A } \\
\text { B } \\
\text { C } \\
\text { D }\end{array}$ & $\begin{array}{l}35,50 \\
35,49 \\
35,50 \\
35,48\end{array}$ & Cholest-5-en-3-ol & 12,01 & 22,55 & 13,12 & 9,45 \\
\hline
\end{tabular}


Tabel 1 di atas menunjukkan bahwa metil ester yang terbentuk paling tinggi hanya diperoleh 49,95\% (methyl palmitate, methyl-9octadecenoate, methyl-3-oxooctadecanoate) yaitu pada agitasi dengan putaran searah. Agitasi 2 arah memberikan hasil metil ester rata-rata sebesar $30,41 \%$. Dari data tersebut nampak terjadi penurunan jumlah ester pada saat diperlakukan dengan agitasi 2 arah baik dalam interval 5 menit $(30,34 \%), 10$ menit $(29,97 \%)$ maupun 15 menit $(30,94 \%)$. Perolehan metil ester yang sedikit ini dapat diduga dikarenakan bahan baku minyak jelantah yang sangat buruk. Hal ini dapat diindikasikan dari angka asam yang cukup tinggi yaitu $8,11 \mathrm{mg} / \mathrm{mL}$, serta banyaknya komponen kimia selain trigliserida yang dapat mengganggu atau menghalangi terjadinya kontak antar reaktan (kitosan, metanol dan trigliserida). Dalam penelitian ini, diketahui senyawa-senyawa yang tercantum dalam tabel 1 memiliki kelarutan yang baik dalam metanol yang merupakan salah satu reaktan penting dalam reaksi transeterifikasi. Pengotor ini dapat berasal dari sumber makanan yang digoreng, senyawa-senyawa yang disebabkan oleh pemanasan yang sangat tinggi, dan senyawa-senyawa yang terbentuk dari reaksi antara asam lemak dengan komponen kimia makanan seperti protein,turunan aldehida/keton/alkohol/asam karboksilat dan sebagainya.

Menurut Sanli H., (2011), selama proses penggorengan secara kontinyu atau berulang-ulang, minyak mengalami pemanasan tinggi dan pada saat yang sama mengalami kontak dengan udara dan air yang terkandung dalam makanan. Terdapat 3 reaksi degradasi penting dalam kondisi ini diantaranya:

1. Reaksi hidrolisis oleh air menghasilkan asam lemak bebas, mono- dan digliserida

2. Reaksi oksidasi yang disebabkan adanya kontak dengan oksigen. Reaksi ini akan menghasilkan senyawa trigliserida teroksidasi meliputi senyawa monomer, dimer maupun oligomernya serta menghasilkan zat volatil seperti senyawa aldehida, keton dan amida.

3. Reaksi polimerisasi yang terbentuk dari senyawa hasil 2 reaksi di atas pada temperatur tinggi. Reaksi ini menghasilkan trigriserida dimer dan polimer dengan struktur cincin.

Menurut Romano (2013), minyak yang dipanaskan tiap 4 jam berulang-ulang selama 40 jam meghasilkan senyawa organik volatil C18:2 (cis-9, cis-12), (E,E)-2,4decadienal dan (E)-2-undecenal yang makin tinggi tiap periodenya.

Selain banyaknya senyawa pengotor, kecilnya hasil metil ester dapat dipengaruhi oleh kurangnya kecepatan agitasi yang hanya dilakukan pada kecepatan $30 \mathrm{rpm}$.

\section{Kesimpulan}

EKSAKTA Vol. 13 No. 1-2 Agustus 2013 
Dari penelitian ini dapat disimpulkan bahwa pola agitasi dengan putaran searah memberikan jumlah metil ester yang lebih tinggi $(49,95 \%)$ dibandingkan dengan putaran 2 arah baik dengan interval pergantian putaran 5 menit $(30,34 \%), 10$ menit $(29,97 \%)$ maupun 15 menit $(30,94 \%)$. Perolehan metil ester yang sedikit ini dapat diduga dikarenakan bahan baku minyak jelantah yang sangat buruk. Hal ini dapat diindikasikan dari angka asam yang cukup tinggi yaitu $8,11 \mathrm{mg} / \mathrm{mL}$, serta banyaknya komponen kimia selain trigliserida yang dapat mengganggu atau menghalangi terjadinya kontak antar reaktan (kitosan, metanol dan trigliserida). Kecepatan agitasi yang hanya $30 \mathrm{rpm}$ juga dapat menjadi faktor lainnya.

\section{Ucapan Terima Kasih}

Penulis mengucapkan terima kasih kepada

Direktorat Perguruan Tinggi (DIKTI)

Departemen Pendidikan dan Kebudayaan

Republik Indonesia yang telah memberikan dukungan dana penelitian ini melalui Program

Penelitian Hibah Bersaing tahun anggaran 2012.

Pustaka

Parawira, W., 2010, Biodiesel production from Jatropha curcas: A review, Scientific Research and Essays Vol. 5(14). 17961808

Patzer R. and Norris, M., 2002, Evaluated Biodiesel Made from Waste Fats and Oils, Final report, Agriculture Utilization Research Institute, University of Minnesota, Minnesota.
Romano, Raffaele; Giordano, Anella; Le Grottaglie, Laura, Manzo, Nadia; Paduano, Antonello; Sacchi, Raffaele; and Santini, Antonello, 2013, Volatile Compounds in intermittent frying by gas chromatography and nuclear magnetic resonance, European Journal of Lipid Science and Technology Vol.115 p.764-773, July 2013.

Sanli, H., Canakci, M., and Aptekin, E., 2011, Characterization of Waste Frying Oils Obtained from Different Facilities, World Renewable Energy Congress, 8-13 May 2011, Linkoping, Sweden

Srivastava, A. and Prasad, R., 2000, Renewable Sustainable Energy Rev., 4, 111-133.

Tatang S.J., 2011, Pengaruh Variasi Berat Kitosan sebagai Katalis Basa Heterogen pada Reaksi Transesterifikasi Minyak Jelantah, EKSAKTA Vol. 12 No.2 Agustus 2011

Yoeswono.,Triyono., Tahir, 1., I., 2008, Kinetika Transesterifikasi Minyak Sawit dengan Metanol Menggunakan Katalis Kalium Hidroksida, FMIPA UGM , Sekip Utara Yogyakarta.

Zappi, M., Hernandez, M., Spark, D., Horne, J. and Brough, M., 2003, A Review of the Engineering Aspects of the Biodiesel Industry, MSU Environmental Technology Research and Applications Laboratory Dave C. Swalm School of Chemical Engineering Mississippi State University, Mississippi.

Anonim, 2004, Preparing for the Chemistry AP Exam. Upper Saddle River, New Jersey: Pearson Education,. 131134. ISBN 0-536-73157-8 